\title{
Employee's Perception of Fairness of Advancement: Implications for Fair Labour Practices
}

\author{
Kola O. Odeku \\ Faculty of Management and Law, School of Law, \\ University of Limpopo, South Africa \\ Email:kooacademics@gmail.com
}

Doi:10.5901/mjss.2013.v4n13p867

\begin{abstract}
Advancement and promotions in the workplace are very sensitive and emotional issues. An organisation's policy and procedures usually stipulate how promotions should be conducted and various roles to be played by those who have the responsibility to commence and finalise promotional processes. The important aspect of the processes is to make sure that there is fairness throughout the processes. Fairness in this sense connotes that the laid down policy and procedures for promotion must be followed and applied by giving all applicants fair and equal opportunities. The perceptions of the applicants become more important and crucial where it is discovered that there was unfair labour practice inherent in the processes that led to advancement. Against this backdrop, fairness or lack of has serious implications on the concept of fair labour practice and the outcome of the selection processes. Consequently, if promotion is perceived by an applicant as unfair, it might trigger agitation, which in turn may lead to quest for redress before the relevant adjudicating authority. Against the backdrop of this problem, this paper seeks to examine applicants' perception of the fairness of promotion processes and the consequences of unfairness in selection, promotion and advancement
\end{abstract}

Keywords: Promotions, Employees, Perceptions, Fairness, Selection Processes, Unfair Labour Practices

\section{Introduction}

The issue of promotion is very sensitive in any organisation and, as such, it is expected that it should be treated with the high standard of professionalism by those who have the responsibility to either confer or not-to-confer promotion unto a candidate. Promotion or advancement would have taken place if an employee advances or progresses to a higher position in an organisation (Garbers, 2001). However, in most cases, employees are regularly evaluated through internal processes by their superiors or assessors before any advancement or progression could transpire. Alternatively, such could also be informed by responding to an advertisement (Grogan, 2009). In that case, if the current employee is found appointable and got the job, promotion would thus have also occurred. Pursuant to this, there are various reasons that may motivate for either a promotion of an employee or not (Meyer, 2004). It could be as a result of the commitment of the employee, leading to attainment of set goals; if it is internal workplace promotions whereby there would not be any need to advertise in order to solicit applications from those who would meet the requirements.

With regard to applicants applying externally, the promotion exercise may not be too problematic. However, with regard to internal promotion, this may be problematic for various reasons. An internal applicant for promotion is already an employee of the company and must have been involved in various issues that would probably impact on whether he should be promoted or not. Being an insider, the applicant is already contaminated in one way or another. If there is more than one applicant vying for a single position in the organisation, the race and competition become more tedious and sometimes full of suspicions. In most cases, whoever succeeds in being promoted may face a lot of challenges at the end of the day from those who were not promoted.

Therefore, the task of those administering promotion is thus to see and ensure that there is fairness and justice in the exercises. However, the issue of fairness is also subjective. What is considered fair to one person might be perceived as unfair by the other. The issue of fairness is very significant at the workplace. An aggrieved person who ought to be promoted but denied will not only consider the procedure and the processes unfair, but can only take further steps by approaching an appropriate court to seek redress and damages. 


\section{Objective}

A lot of issues usually arise regarding promotion in the workplace, especially if it is perceived that there have been unfair practices during the promotion process or procedure. Undoubtedly, this will definitely affect the employee who is aggrieved with the process and may also impact the workplace environment by making people to be disgruntled and not want to put in their best because of the perception that, when it comes to upliftment, the employer might act unfairly. Therefore, the key objectives of this paper are to consider when promotion will be regarded as either fair or unfair and the reaction of the parties involved. If it is unfair, what are the appropriate steps and remedies that can be explored by an aggrieved employee to ensure that fair labour practice is restored in order to protect the right to fair labour practices.

\section{Problem Statement}

In the workplace, promotion that is done outside of the principles of fairness is destructive and invites unnecessary and unwarranted litigations. Although, several court cases have proven that both substantive and procedural fairness are key in the promotion of employees in a workplace, some of the employers are seen to be reluctant in taking these pivotal principles of fairness very seriously, thereby continuing to incur litigious costs that are unwarranted. Although it is trite law that the employers are not bound to promote their employees to higher positions, however, when such situations arise, they are bound to act fairly and within the boundaries of the LRA.

\section{Methodology}

The methodology for this study was reliance on the literature relevant to how an applicant, who had been unfairly treated during promotional exercises, perceived the overall procedures from the beginning to the end. As part of the argument to justify whether a promotional exercise was fair to us, the study accentuates on the need to follow the laid-down procedure and policy of the company or establishment seeking to hire or promote employees. This position is supported by laws and regulations of many countries, including South Africa. The study also presents consequences for non-compliance with the laid-down procedure and policy, and submits vehemently that failure to comply will vitiate the selection processes and the aggrieved party can approach an appropriate court to seek redress, and appropriate remedies and reliefs may be granted and ordered. However, the study indicates that the decision to appoint is incumbent upon the employer, provided the laiddown procedure and policy have been followed. Therefore, what an employer needs to do is to apply its mind and appoint a suitable person for the job, not necessarily the best or the person who scored the highest mark.

\section{Literature Review}

At common law, the issue of promotion is not contestable unless it is enshrined in the contract of employment detailing criteria for promotion. Against this backdrop, an employee has no legal right or entitlement to insist on promotion to the next or any higher post, except if the contract of employment explicitly spelt out the conditions regulating promotions in the contract of employment (Shapiro and Tune 1974). It is in this regard that an employee could make a claim in terms of those conditions. Therefore, if an employer refuses to apply its mind by promoting an employee, the employee has no legal right to institute an action against the employer and claimthat the employer acted unfairly (Van Jaarsveld, 2008). For this and other reasons, this is why the State has to intervene by enacting laws to protect the rights of employees against unfair labour practices (Peck, 1979).

Pursuant to this, if the contract does not stipulate promotional issues, an employee cannot institute an action in court to compel it (Estreicher, 1997). Even if an action is instituted, the defendant may raise the issue of jurisdiction and submit that the court has no jurisdiction to entertain or hear such case (Carrington and Haagen 1996). In South Africa, the Labour Relations Act has come to rectify this anomaly, thus promotions are recognised under the law (Bhorat et al. 2002). An employee who is entitled to or denied promotion by any means by the employer can approach the court and the CCMA and sue for unfair labour practice (BhoratandVan der Westhuizen 2009). When the legislature enacted the LRA into law, the purport is to regulate all conditions of employment in a work place and draw the lines where necessary. Workers have rights even though the employer is the owner of the business. Consequently, both employer and employee's acts are regulated by the LRA and by the Constitution of the Land. With regard to the issues of unfair labour practice in promotional exercises, an employer will be considered to have contravened Section 186(2)(a) of the LRA and would be found civilly liable for unfair labour practices pertaining to any form of unfair conducts relating to the promotion, advancement, elevation, demotion, probation or training of an employee (Okpaluba, 1999). 
It is important to mention that it is the prerogative of an employer to either hire or not any person to a vacant post whether it is a promotion or not (Stevens, 1996). An employer can also decide to create or freeze a vacant post or refuse to appoint a new person (Gould, 2009). What is legally important is that, whenever an employer decides to recruit, the law will set in, hence the employer must ensure that the process is fair and objective in order not for the selection process to end up being litigated; as this sometimes could be a set back to the day to day running of the business of the employer (Verkerke, 1998). Litigation will consume money and time, and will probably leave the post to be filled vacant for years until the court finally makes a judicial decision (Epstein, 1998). The employer must ensure that, procedurally, there is full compliance with the provisions of the law in order for the process not to be declared as unfair labour practice (Furlong, 1984). Consequent upon this, an employer is not compelled to promote or to hire to fill a post, but if this has to be done, then good faith, fairness and objectivity should be apparent and displayed in all the processes (Weston, 2001).

Except the employer acted unfairly during promotional exercises, an employee cannot insist that he should be promoted to a higher post (Cooper and Sobol 1969). However, if the employee can show that the employer's act during the processes was unfair and the selection was unfair and biased, which thus prejudiced his being promoted, there and then, the employee can raise the issue of unfair labour practice (Arvey, 1979). It is only with regard of this that an employee can raise unfair labour practice, otherwise if the employer's act is in line with company policy and procedure, and conforms with the LRA and the Constitution, the employee will not sustain the issue of unfair labour practice, if raised.

The issue of fairness with regard to promotion should be based on an objective test (Crawshaw, 2006). It is what any reasonable person can see and should be able to take a stand on whether it is fair or not. By evaluating the decision, process, procedure and all ancillary issues related to the decision, one should be able to see whether the decision taken is fair or not. A study by Truxillo et al., (2004) dealt extensively with the question of when fairness should matter in selection procedures. They also examined the usefulness of the organizational justice approach to applicant reactions and organisational outcomes. These are necessary in view of the fact that whoever is selected will impact the person's career and also advance the key business of the organisation in terms of performance and efficiency.

Similarly, the issue of perception of fairness and in particular, procedural fairness has shown that this impact on the psychological experiences and behaviours of employees shown to affect a wide assortment of people's psychological experiences and behaviours (Brockner et al. 2008). When the selection procedure used was fair, people perceived it as credible and therefore reacted positively to the outcome of the selection processes. In case of malicious grievance against such decision, people will react by supporting the company on the basis that the processes were transparent and devoid of suppression of views. In most cases, if the processes were challenged for one reason or another, the employer will likely get the support of other employees to provide credible evidence in case of any dispute (Brockner et al. 2008).

The study conducted by Harel et al., (2003) revealed that fairness in promotion could be a motivating factor for high performance to an applicant who was selected during the promotion. It enhances confidence and self-esteem, and confirms that, through healthy competition, the person selected deserved to be selected to the position because he met all the requirements of the selection processes.

The study conducted by Adebayo (2005) showed that when fairness is observed in a workplace by the leadership, employees are motivated by this, and where it is the contrary, employees are least motivated. Applying this finding, if promotion is based on fairness to all concerns and the procedures are diligently followed, no matter the outcome, the other employees would be satisfied and be motivated to work harder with the hope that when such an opportunity arises, if they apply, they stand the chance of being selected. If the processes are not fair, they become a source of disincentive and can lead to disillusionment and complacency whereby employees might start thinking that no matter how hard working or qualified for the job one is, if the opportunity arises, one may not get it.

According to García-Izquierdo et al. (2012:394), fairness in promotions is a core issue for organizations as it is directly related to some of the most important organizational outcomes". García-Izquierdo et al., (2012:394) accentuate that workers' perceptions of promotion systems have impact on the organizational justice and job satisfaction. If the promotion methods are perceived to be transparent, they will consider this as procedural justice and that the method is fairer based on assessment of performance. In this sense, transparency is considered as an important antecedent of Procedural Justice. In all respect, procedural fairness will always result to job satisfaction (García-Izquierdo et al. 2012).

Elkins et al.'s (2003) study dwelled on the issues of gender and affirmative actions in the workplace. Their study revealed that in in an affirmative action environment, the promotion of a female usually resulted into positive or negative perceptions. The follow up is usually a lot of insinuations and guess work irrespective of whether the female has really proved herself, this is common in a workplace. Bald and McBrier (1997) examined promotion tied to race, especially the Black and White phenomenon in the USA. They pointed out that, if promotion is race blind, there is a tendency that Blacks or Whites with required qualification can get the job. In the final analysis, their study revealed that that the 
determinants of promotion systematically differ for Blacks and Whites. Whites are always getting promoted in the workplace over Blacks, even where Blacks are doing the same job. In South Africa, these days, the reverse is the case. In view of the numerous policies promoting Black empowerment and affirmative actions, Blacks, especially females, are always treated favourably regarding promotions at the workplace (BaldandMcBrier, 1997).

Janssen's (2000) study demonstrated that employee who is creative and productive should be rewarded and those that are not should not be. If hard work is rewarded, employee will perceive this as an effort-reward fairness rather than under-reward unfairness. Pursuant to this, if a hardworking employee is denied promotion, it will amount to under-reward unfairness.

\section{A Consideration of Issues Surrounding Fairness}

In the workplace, it is not surprising to hear employees complain of fairness or unfairness of activities going on whether with regard to workload, disciplinary issues, promotional and so on, working conditions, salary, discrimination, company's policy, promotions and demotions and so on (Harris et al. 2008). The conclusion to be drawn from these issues is the concerned about fairness or the lack of, followed by the consequences and expectations for violation. This is why, in an organisation, selection context is replete with examples of situations where there are suspicious, favouritisms, discriminations on numerous grounds and so on. In most cases, a person is refused a job based on these situations while in another in another; a person is favoured and offered a job. These situations usually trigger action and reactions by the aggrieved person who was not offered the job. At this stage, the aggrieved person, together with those who believed there was unfairness in the processes, will consider the outcome not credible. As long as the right thing is not done, such appointments will always generate controversy (ArveyandRenz, 1992).

Fairness issues can also be used in consideration of dispute resolution (Delgado et al. 1985). This usually happen during adjudication processes. The presiding or the adjudicating authority would want to ensure that the outcome is fair to all concerns. In promotion cases, fairness issues also appear prominently. Considering that this relates to labour issues, it is tested from the enabling law regarding any labour issue being considered. Therefore, because of its unique position, fairness appears prominently in the Constitution and the Labour Relations Act. The panellists to adjudicate promotion are therefore expected to be fair. This is a statutory requirement under numerous laws. Being fair is following the laid-down rules, procedures and policy guiding and regulating the process. By following this step, it will make the process credible and reduce the possibility of consternation of the outcome of the process.

However, if a member is biased and decides to be part of the processes throughout, this issue may be raised by the affected employee at the appropriate time. Usually, during redress, where the process will be subjected to scrutiny and review, this and other challenges need to be properly taken care of in order to have and present an acceptable outcome which will be perceived to be fair procedurally and substantially. The prejudiced panellist may get away with his act if no one contests the outcome of the selection process. Legally, this is proper. However, if it was discovered that the member was biased against any of the candidates, moral conscience will definitely judge such a member. Apart from the issue of conscience, the member would be perceived to have directly or indirectly compromised the section through his or action as this will lead to the appointment of less qualified person. The result of this is not far-fetched, the appointed person might not be able to perform and deliver based on the requirements of the job. Undoubtedly, this will definitely impact the company or establishment. This has always been the case with regard to cadre deployment under the policy of the African National Congress (ANC) in South Africa. Unqualified people are always selected to do jobs that require skills and expertise. On assumption of office after appointed, they become disservice and render poor performances and services to the people. Persistent violent service delivery protests across the country bear witness to the appalling level of poor service delivery by deployees.

Against the backdrop of ensuring procedural justice and fairness in selection processes, there are important principles that have been developed overtime and considered as basic and vital elements, which are used as yardsticks to assess whether there has been procedural justice and fairness in selection procedures. The principles are as follows: Objectivity, wherein the processes of selections should be open, fair, equitable and objective up to the conclusion reached; Consistence, this is expected to apply across the applicants. All applicants for the job must be treated equally and fairly. The rules must be consistent and not deviated from. Discrimination on the grounds of gender, sexual orientation, colour and religion should be discouraged. All applicants should be subjected to almost similar questions during interviews and time allocated should also be consistent throughout. The process should not be subject to manipulation where an applicant will stand in a vantage position against others. All applicants are expected to be assessed based on a common set of criteria and standard. Political ties and external meddling would be unfair and unjust. Examples of how political interference plays a major role in appointments in the public sectors abound in South 
Africa. Cadre deployments have taken over real and formal selection processes. At the end of the day, unqualified and untested cadres will be appointed. Professionals should be in charge of selection processes and not mediocre.

Professionalism strengthens the processes because the people selecting are considered knowledgeable and can make good decisions that will assist the process. Confidentiality is very important. The confidentiality of the procedures must be maintained. The information of the process should not be released so also the identities of the applicants scores, tests items and the one that was adjudged the best during the interviews. Release of information should always be through official sources; otherwise the process will be discredited and weakened. Most importantly, the panel must be diversified and consist of different persons with different perspectives and constituencies. For instance, if the selection for advancement is at a university or an academic setting, it is important to have different persons constituting the interview panel, from the academia, labour unions, students' representatives and the human resources. These people, representing different constituencies with the university community, will ask questions, based on their backgrounds, to the applicants based on the procedures and policy. Thereafter, collectively, the panellists will apply their minds and select the most suitable or appointable candidate for the job (ArveyandRenz, 1992).

\section{Promotions are Prerogative of Employers but Must be Substantive and Procedurally Fair}

Even though an employer has the right to either promote or not, whatever decision is taken, it must be procedurally and substantively fair otherwise the process will be nullified and declared invalid. This is applicable in both private and public sectors. Failure to follow due processes will usually attract unpleasant consequences. Hence, it is imperative for an employer to get it right and not blunder. Consequently, at all times, it is incumbent upon the employer to have reasonable and convincing reasons for promoting an employee. In case an aggrieved applicant challenges the decision and becomes successful, the employer will be guilty of unfair labour practice. To avoid this type of scenario, the employer should ensure that the decision to promote is based on well-founded and correct principles and reasons by demonstrating convincingly that the applicant that is promoted is well suitable for the position. As Du plessis2002) puts it, there must be a logical connection between the real reason and the decision taken (Du plessis, 2002). But this issue of substance and being objective might be dicey sometimes. It poses a lot of challenges to the employer because the decision to prefer one applicant over another is always problematic in the workplace. An employer needs to balance all interests, apply its mind to ensure that there is no favouritism, that, all things being equal, all parties are given fair hearing,' and that there is no element of bias prior, during and after selection processes.

However, it is necessary to point out that even if an employer would have followed and complied with due processes diligently, this employer has the discretional right not to employ the best suitable person. The employer reserves the right to choose whoever it considers to be the best candidate and this will always be upheld, unless there is discovery of elements of mala fide or that the promotion was done arbitrarily.

The employer may set some acceptable standard for considerations of promotional processes. This will assist in scrutinising the decision to be taken before final promotion is made. The employer may set a certain hierarchy to the stated requirements. But during interviews, the employer may not ask questions on all the standard set. Most importantly, this will not render the process invalid because it is just a guide that may be used as standard to ask questions. The employer can also deviate from the marks scored. If the person who scored the highest marks during the interview is not appointed, this will not jeopardise the appointment of the person who might have scored lower marks but was found appointable. Provided the employer followed its policy on ratings and duly applied its mind during the selection process, the decision to hire or promote person with a lower marks will not be fatal to the processes. This is the general practice in South Africa. The fact that a particular candidate obtained more marks in the interview is immaterial when it comes to the issue of appointment of a successful candidate; the panellists will appoint by applying their minds, not by virtue of marks scored by the candidates. The panellists therefore have the right to deviate from the marks scored and only apply their minds and appoint the best suitable candidate for the job. One important point that needs emphasise always is to admonish employers or their managers and superiors not to promise any contending candidate for a job or promotion; that come rain or sunshine, the applicant will be hired or promoted. In some cases, the panel needs to recommend to a higher body before promotion can be approved, that is, if the practice is that, whenever a recommendation to the highest body is made, there will be promotion. However, it is important to mention that there could be deviation from this practice. If the applicant recommended is not appointed by the higher body, it will not be fatal to the process. What needs to be established is whether the higher body has applied its mind. If this is proven to be correct and confirmed, that will not be unfair labour practice.

The issue of affirmative action and denial of promotion to some of the employees who fall within a designated group is very problematic and challenging. Sometimes, employers use this to deny some employees promotions just 
because they fall within this group. This raises the issue of discrimination and needs to be treated in a way that will meet the requirements of the law in order not to prejudice other employees. The law that provides for this type of promotion should be considered and applied fairly and not arbitrarily. Most importantly, during an interview, the panellists need to take all factors into account, including, but not limited to, performances during interviews. It is, however, generally acceptable that if an employer or its selection panel takes into account any consideration that shows that it failed to apply its mind to the matter at hand, the defect will be fatal and the decision thus unfair (Basson, 1998). Perhaps the most obvious example of this would be where the decision of the panel is swayed by outside influences, such as the preference of more senior people in the organization. In general, an employer's conduct is equally important.

\section{Causes and Consequences of Applicant's Perceptions of Unfairness}

Promotion is usually contested when it is advertised internally and sometimes externally where an employee seems to be under the impression that, because of acting on a position for years, the job should normally be given to him or her. To the internal employee, this will serve as an upliftment. However, if anything is done contrary to this, the employee might look at it as injustice and unfair. Consequently, an aggrieved employee might take appropriate steps by instituting an action in court to contest the decision of the panel not to appoint him to the higher position (Sims, 1976).

There are various implications for these and sometimes there are consequences. But the goal of the employer is to hire the best person who can do the job and enhance the performance of the organisation. According to Giolland and Steiner (2001:175), "we need to hire the best and brightest. The best and brightest are usually in high demand at other companies, so we have to make sure we create our applicants well. That is part of our competitive advantage". Giolland and Steiner (2001:175-176) continue thus: "we want to do everything we can to make sure that each experience an employee has with our company is a positive one. This starts with interview process because first impression often extends through an employee's entire stay with the company".

Therefore, an applicant's perception is considered important because such affects an applicant's job and how he performs upon assumption of duty. There are also different consequences for this.Giolland and Steiner (2001:175-176) point out that "our applicants are also potential customers. When we interview applicants we are not only in an assessment mode, but also in a selling mode. We strive to create a comfortable, hassle-free experience for our applicant".

Also important is the issue of fairness in procedure and practices during the process. If the applicant perceives that these were not followed as stipulated, it will impact on justice. This is because organisational justice entails procedure and concerns of distributive justice. Hence the concepts of fairness and justice are closely linked. As such, issues relating to perceived fairness or justice, terms which are used interchangeably by researchers, are entrenched in the workplace.

\section{Remedies for Denial of Promotion as a Result of Unfair Labour Practice}

An aggrieved applicant has the right to approach an appropriate adjudicating institution to seek redress by exploring various statutory remedies available to a victim of unfair labour practice (Peck, 1970). The adjudicating institutions can grant several remedial orders in favour of the unfairly treated employee regarding unfairness in promotional exercises (Kok, 2008).

Adjudicating institutions, mostly the law courts, have fashioned a range of remedies such as a declaratory order, remittal to an employer for consideration, protective promotion, actual promotion, and compensation (Rendleman, 1974).

If there was a predetermined intention to appoint a certain applicant by an employer and the employer so did, but in the course of selection process the employer fails to follow its own procedure (Catz, 1981), this conduct might have potentially prejudiced other applicants. If this is the case, the court has the inherent power to make a declaratory order (Jaffe, 1962).

Another challenging situation is when an employer might have filled the post by itself without giving others who applied to be interviewed a chance (Fowler and Mangione 1990). In this situation, there could be a remedial action of insisting that those other applicants who were not interviewed now be interviewed (Cooper and Sobol 1969). But the issue is that, if the results are out and negative in that the applicants were not appointed, the issue of unfair labour practice will be raised on the ground that the subsequent interviews conducted were tainted by bad faith on the part of the panellists (Cooper and Sobol 1969). However, it will not be appropriate to appoint an unfit applicant. The applicant can only be successful if there is cogent evidence to contradict an earlier appointment made. The problem inherent in this situation is that the applicants who were not selected or given opportunities to be interviewed at the same time when the first selections were made will continue to perceive the processes as being unfair and unjust. 
There could also be a protective promotion. This is a situation where an employee is not promoted to the actual post, but is promoted in rank and remuneration (Byrt, 1966). This remedy is usually used to protect those who are vulnerable to or disadvantaged by a certain policy reason. The court will always come to the aid of the applicant in this situation and protect any promotion that is due by ensuring that the applicant is promoted.

The court can also impose actual promotion. This situation will arise where the aggrieved applicant is contesting the advertised post in the court and during the processes of litigation until it is finalised, if the position has not been filled, the court can, on its own impose actual promotion by giving the position to the aggrieved party (Chayes et al. 1970). This will be a confirmation of getting what the applicant really merited and deserved.

Compensation as a remedy will be availed to an aggrieved employee where, due to procedural irregularity, the applicant's application was not processed for promotion. The selection process will amount to be procedurally unfair in all respects and constitute unfair labour practice. Consequently, failure to present an employee's application before the relevant decision maker constitutes a serious procedural irregularity for which compensation is justified (Boynton, 1986).

\section{Conclusion}

Promotion and advancement in a workplace are very important and serve as incentives for reward of hard work and the need for employees to continue on the path of giving the best to an organisation. But such can also be a very sensitive issue if not handled well. The perception of employees toward promotion can either increase the productivity of a company or decrease it; and sometimes it might even destroy and liquidate the organisation in its entirety. This is why it is important for an employer to be sensitive and ensure that it follows and applies the laid-down policy and procedure during the processes of promotional exercises. Anything done contrary to this will be regarded as unfair labour practice and will attract consequences. However, the mere fact that a preferred candidate for promotion was not appointed does not warrant the process to be declared invalid. What is important is that the employer has applied its mind and followed the procedure and appointed the best suitable candidate. However, if there is failure on the part of the employer to do this, the aggrieved applicant has various remedies under the law that could be explored to redress the unfairness.

\section{Recommendations}

Advancement and promotion can make or mar an applicant, especially when the people who are given the responsibility to promote treat the issues of promotion and advancement with levity and disdain. Knowing fully well that career upliftment is self-fulfilling and can unlock other opportunities, however, if panellists fail to apply their minds, this might negatively impact the career of another person and thus lead to shattered dreams and ambition. While there are remedies available to an aggrieved applicant, this should be explored and an adjudicating body should impose punitive sanction for unfair labour practice. It is also highly recommended that if, prior, during and after selection processes, it is found that a member or panellist acted mala fide - that is, with bad faith and arbitrarily - action should not only be instituted against the employer, but the civil responsibility of any panellist or the entire panellists should also be explored in order to make them accountable for their unfair labour practices.

\section{References}

Adebayo DO2005. Perceived workplace fairness, transformational leadership and motivation in the Nigeria police: Implications for change.International Journal of Police Science and Management, 7(2): 110-122.

Alleyne R 1995. Statutory discrimination claims: Rights waived and lost in the arbitration forum.Hofstra Labour Law Journal, 13:381392.

Arvey RD 1979. Unfair discrimination in the employment interview: Legal and psychological aspects.Psychological Bulletin, 86(4):736765.

Arvey RD, Renz GL 1992.Fairness in the selection of employees.Journal of Business Ethics, 11(5-6):331-340.

Bald S,McBrier DB 1997.Do the determinants of promotion differ for Blacks and Whites? Evidence from the U.S. labor market.Work and OccupationsJournal, 24(4): 478-497.

Bhorat H, Lundall P, Rospabe S 2002. The South African Labour Market in a Globalizing World:Economic and Legislative Considerations Employment. From <http://www.oit.org/wcmsp5/groups/public/---ed_emp/documents/publication/wcms _142363.pdf.> (Retrieved August 16, 2013).

Bhorat $\mathrm{H}$, Van der Westhuizen C 2009. A Synthesis of Current Issues in the Labour Regulatory Environment. From $<$ http://papers.ssrn.com/sol3/papers.cfm?abstract_id=2184167.>(Retrieved September 6, 2013).

Boynton J 1986. Judicial review of administrative decisions-a background paper.Public Administration Journal, 64(2): 147-158.

Brockner J,De Cremer D, Fishman AY, Spiegel S 2008. When does high procedural fairness reduce self-evaluations following 
unfavorable outcomes?: The moderating effect of prevention focus.Journal of Experimental Social Psychology, 44: $187-200$.

Byrt WJ 1966. The idea of a promotions appeal system.Australian Journal of Public Administration, 25(4):297-308.

Carrington PD, Haagen PH 1996. Contract and jurisdiction. The Supreme Court Review, 1996:331-402.

Catz R S 1981. Due process and federal grant termination: Challenging agency discretion through a reasons requirement.Washington University law Quarterly, 59:1067-1074.

Chayes AH, Kaufman CL, Wheeler RL 1970.The university's role in promoting minority group employment in the construction industry. University of Pennsylvania Law Review, 119(1):91-114.

Cooper G,Sobol RB 1969. Seniority and testing under fair employment laws: A general approach to objective criteria of hiring and promotion.Harvard Law Review, 82(8):1598-1679.

Crawshaw JR 2006.Justice source and justice content: Evaluating the fairness of organisational career management practices.Human Resource Management Journal, 16(1):98-2006.

Delgado R, Dunn C, Brown P, Lee H 1985. Fairness and formality: Minimizing the risk of prejudice in alternative dispute resolution.Wisconsin Law Review, 4: 1359-1366.

Du plessis V 2002.A Practical Guide to Labour.Durban, South Africa: LexisNexis, Butterworths.

Elkins TJ, Bozeman DP, Phillips JS, 2003.Promotion decisions in an affirmative action environment: Can social accounts change fairness perceptions? Journal of Applied Social Psychology, 33(6):1111-1139.

Epstein NL 1998. Reducing litigation costs for small cases.Judges Journal, 20:9-17.

Estreicher S 1997. Predispute agreements to arbitrate statutory employment.New York University Law Review, 72: 1344-1356.

Fowler FJ, Mangione TW 1990.Standardized Survey Interviewing: Minimizing Interviewer-Related Error.California, USA: Sage Publication.

Furlong G 1984. Fear and loathing in labor arbitration: How can there possibly be a full and fair hearing unless the arbitrator can subpoena evidence. Willamette Law Review,20:535-544.

Garbers 1999. Promotions: Keeping abreast with ambition.Contemporary Labour Law 21:21-34.

García-Izquierdo AL, Moscoso S, Ramos-Villagrasa PJ 2012.Reactions to the fairness of promotion methods: Procedural justice and job satisfaction.International Journal of Selection and Assessment, 20(4):394-403.

García-Izquierdo AL, Moscoso S, Ramos-Villagrasa PJ 2012.Reactions to the fairness of promotion methods: Procedural justice and job satisfaction.International Journal of Selection and Assessment, 20(4):394-403.

Giolland SW, Steiner DD 2001. Causes and consequences of applicant perceptions of Unfairness. In: Russell Cropanzano (Ed.):Justice in the workplace: From theory to practice. New Jersey, USA, Lawrence Erlbum Associates Publishers, pp. 175-189.

Gould WB 2009. New Labor Law Reform Variations on an Old Theme: Is the Employee Free Choice Act the Answer?Labour Law Review, 70:1-11.

Grogan J 2009.Workplace Law, Juta and Company Ltd, Cape Town, South Africa.

HarelG, Tzafrir S, Baruch Y2003. Achieving organizational effectiveness through promotion of women into managerial positions: HRM practice focus. The International Journal of Human Resource Management, 14(2):247-263.

Harris L, Tuckman A, Snook J 2008. Small Firms and Workplace Disputes Resolution.From <http://www.acas.org.uk/media/pdf/6/e IAcas 0108 Small firms workplace_disputes_resolution.pdf> (Retrieved July 19, 2012).

Jaffe LL 1962. Exhaustion of administrative remedies.Buffalo Law Review, 12:327-336.

Janssen 0 2000. Job demands, perceptions of effort-reward fairness and innovative work behaviou, Journal of Occupational and Organizational Psychology, 73(3):287-302.

KokA 2008. Promotion of equality and prevention of Unfair Discrimination Act 4 of 2000: Proposals for legislative reform.South African Journal on Human Rights, 24:445:456.

Meyer JP, Becker TE, VandenbergheC 2004. Employee commitment and motivation: A conceptual analysis and integrative model. Journal of Applied Psychology, 89(6): 991-1007.

Okpaluba C 1999. Reinstatement in contemporary South African Law of unfair dismissal: The statutory guidelines.South African Law Journal, 116:815-829.

Peck C J 1979. Unjust discharges from employment: A Necessary Change in the Law, Ohio State Law Journal, 40:1-9.

Peck CJ 1970. Remedies for racial discrimination in employment: A comparative evaluation of forums.Washington Law Review, 46:455464.

Rendleman D 1974. New due process: Rights and remedies.Kentucky Law Journal, 63:531-542.

Shapiro JP, Tune JF 1974. Implied contract rights to job security.Stanford Law Review, 26(2):335-369.

Sims H W 1976. Uncertain status of public sector labor arbitration in Colorado. University of Colorado Law Review, 48:451-462.

Stevens S 1996. What works and what does not in career development programmes.Emerald Journal, 1:11-18.

Truxillo DM, Steiner DD, Gilliland SW 2004. The importance of organizational justice in personnel selection: Defining when selection fairness really matters.International Journal of Selection and Assessment, 12(1):39-53.

Van Jaarsveld Ml 2008.Contract in Employment: Weathering Storms in Mixed Jurisdictions? Some Comparative Thoughts.From http://ejcl.org/121/art121-26.pdf.(Retrieved October 17, 2013).

Verkerke JH 1998. Legal regulation of employment reference practices. The University of Chicago Law Review, 65(1):115-178.

Weston MA 2001. Checks on participant conduct in compulsory ADR: Reconciling the tension in the need for good-faith participation, autonomy, and confidentiality.Industrial Law Journal, 76:591-603. 